psychologists. The catalogue of books was prepared by four $\mathrm{PhD}$ candidates at the Faculty of Journalism, Information and Book Studies, University of Warsaw: Anita Kwiatkowska, Daiwa Maksimowicz, Dagmara Sidyk and Marlena Sztyber. Over a couple of months they worked on the Library under the supervision of Alicja Jaskiernia (University of Warsaw) and Michał Głowacki (University of Warsaw).

Text: Anita Kwiatkowska, Daiwa Maksimowicz, Dagmara Sidyk, Marlena Sztyber Photo by: Ewa Łukomska-Janek, the Faculty of Journalism, Information and Book Studies,

University of Warsaw

\title{
The Media and Democracy Karol Jakubowicz Award
}

Since 2018 the Polish Communication Association has been an institutional partner of the Media and Democracy Karol Jakubowicz Award. The Award was established by Małgorzata Semil-Jakubowicz; it is granted to outstanding contributions in the areas of scientific interests of Karol Jakubowicz. The overall goal is to support scholars who contribute to the studies on democracy, human rights, policy-making, media ethics, and public service media. The Executive of the Award includes Iwona Hofman (President of the Polish Communication Association), Małgorzata SemilJakubowicz (Founder of the Award), Hanna Machińska (Deputy Commissioner for Human Rights, Poland), Alicja Jaskiernia (University of Warsaw), Beata Klimkiewicz (Jagiellonian University), Elżbieta Matynia (The New School for Social Research), Halina Rostek (The National Broadcasting Council), and Michał Głowacki (Editor-in-chief, Central European Journal of Communication).

In 2018 the Awards were granted to Maria Nowina Konopka (Jagiellonian University) and Jakub Nowak (Marie Curie-Skłodowska University in Lublin). An award for long-time contributions to the theory and practice of public service media was granted to Christian S. Nissen, international expert and former Director-General of Danmarks Radio. In 2019 the Media and Democracy Karol Jakubowicz Award was granted to Małgorzata Adamik-Szysiak (Marie Curie-Skłodowska University in Lublin) and Maria Łoszewska-Ołowska (University of Warsaw).

In 2020 the Executive and previous award winners nominated six books for the Media and Democracy Karol Jakubowicz Award with - for the first time ever a book published outside Poland. This is a part of an internationalization strategy adopted by the Executive during the meeting at the Bureau of Commissioner for Human Rights in Poland. Nominating books for next year's edition will be a joint initiative of Polish and international scholars. The Award winner is announced on April 28th, the day of the passing away of Karol Jakubowicz. 

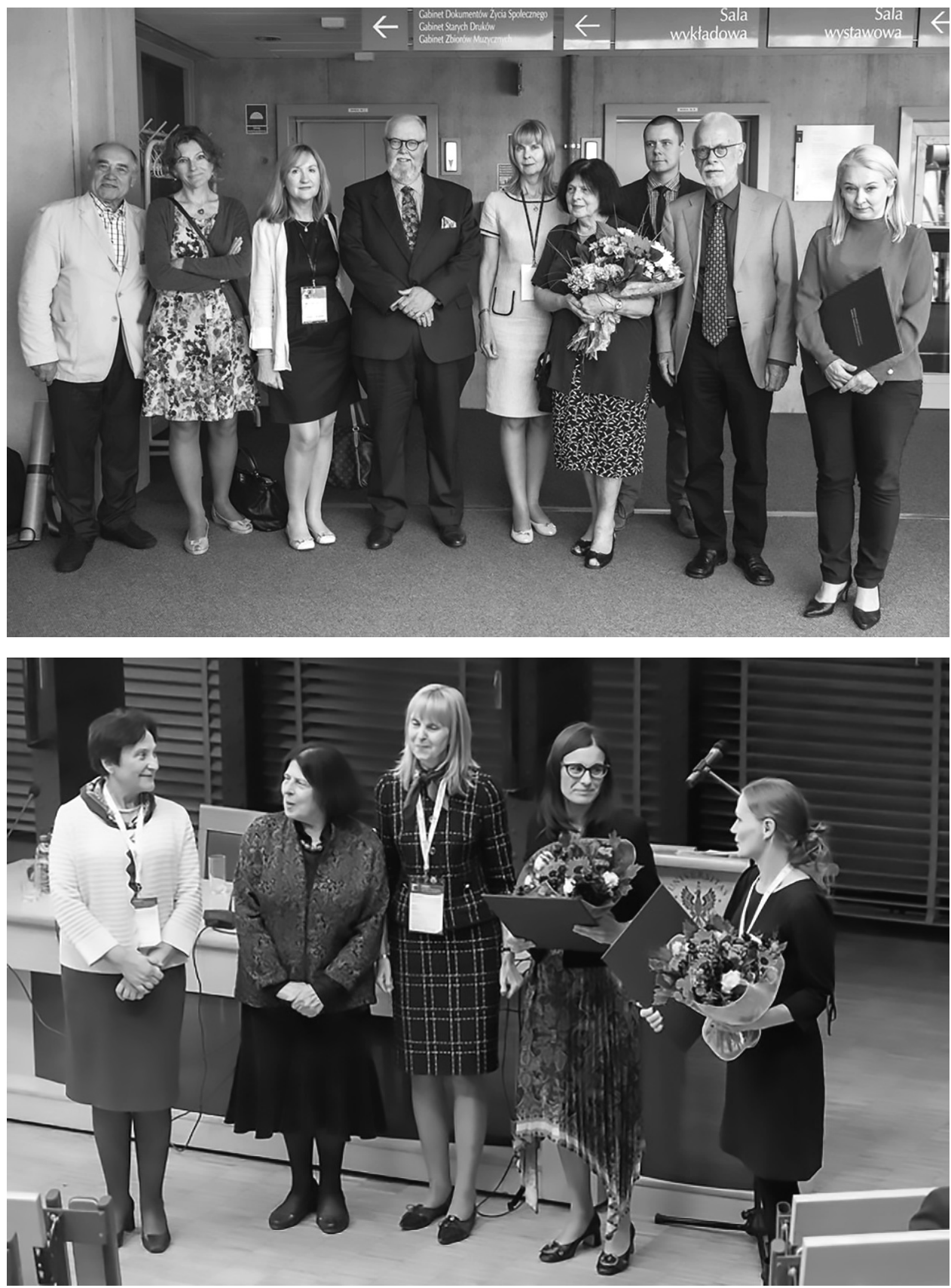

Photo: Winners of the first and the second edition of the Media and Democracy Karol Jakubowicz Award during the Award ceremonies: conference of the European Media Management Association (Warsaw, June 15, 2018) and 5th Congress of the Polish Communication Association (Warsaw, September 19, 2019) 
The following books were nominated for the Media and Democracy Karol Jakubowicz Award in 2020:

1) Maja Chacińska "W służbie ludu i inżynierii społecznej. Media publiczne w Danii, Norwegii i Szwecji w perspektywie historycznej i kulturowej" [In the service of people and social engineering. A comparative study on history and culture of public service media in Denmark, Norway and Sweden] (Gdańsk: Wydawnictwo Uniwersytetu Gdańskiego, 2018).

2) Katarzyna Gajlewicz-Korab "Francuska prasa drukowana. Narodziny, rozwój, era cyfrowa" [Printed press in France: Beginnings, developments and the digital age] (Warszawa: ASPRA-JR, 2018).

3) Marta Jas-Koziarkiewicz "Euronet Plus. Europejski głos w twoim domu. Radio w procesie europeizacji” [Euronet Plus. A European Voice in your house. Radio in the process of Europeanisation] (Warszawa: Dom Wydawniczy ELIPSA, 2019).

4) Sabina Mihejl and Simon Huxtable "From Media Systems to Media Cultures. Understanding Socialist Television" (Cambridge: Cambridge University Press, 2018).

5) Agnieszka Walecka-Rynduch "MediaEgo w MediaPolis. W stronę nowego paradygmatu komunikowania politycznego" [MediaEgo in MediaPolis. Towards a new paradigm in political communication] (Kraków: Wydawnictwo Naukowe Uniwersytetu Pedagogicznego w Krakowie, 2019).

6) Mirosława Wielopolska-Szymura "Rozgłośnie BBC World Service, Radio France International i Voice of America w komunikowaniu międzynarodowym" [BBC World Service, Radio France International and the Voice of America in international communication] (Katowice: Wydawnictwo Uniwersytetu Śląskiego, 2019).

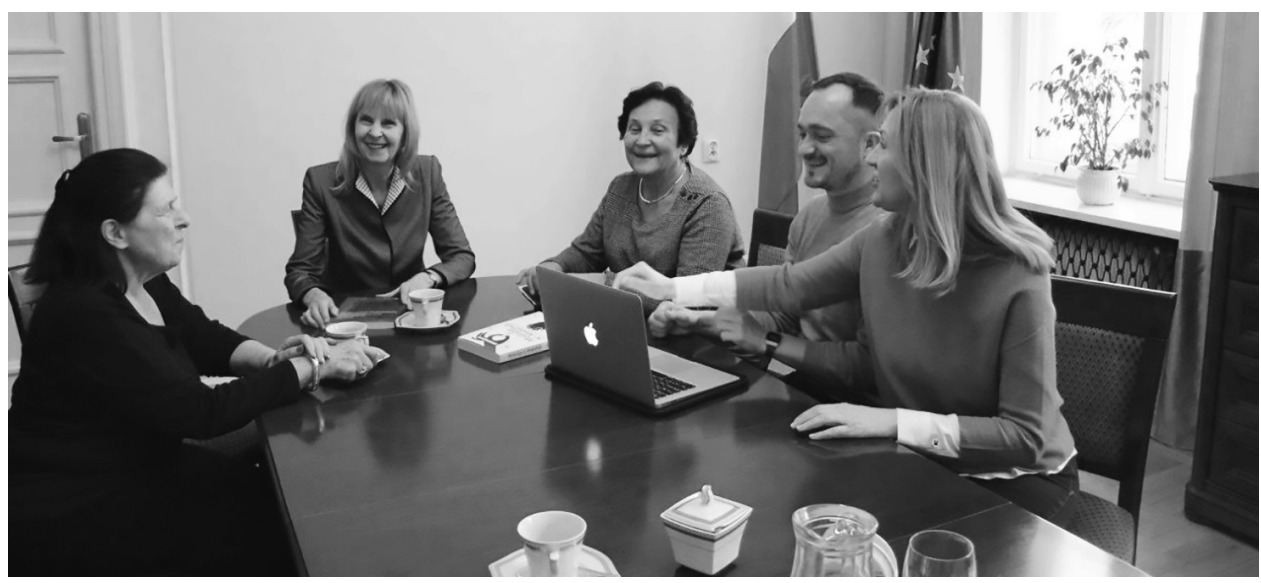

Photo: The Executive decides on nominated books for Media and Democracy Karol Jakubowicz Award (Warsaw, March 11, 2020)

Authors: Michał Głowacki and Dagmara Sidyk Photos by: Faculty of Journalism, Information and Book Studies, University of Warsaw and the Office of the Commissioner of Human Rights, Poland 